\title{
Doing Team Ethnography in a Transnational Prison
}

\author{
Alison Liebling ${ }^{1}\left({ }^{10} \cdot\right.$ Bethany E. Schmidt ${ }^{1} \cdot$ Kristel Beyens $^{2} \cdot$ Miranda Boone $^{3} \cdot$ Berit Johnsen $^{4} \cdot$ Mieke Kox $^{5}$. \\ Tore Rokkan ${ }^{4} \cdot$ An-Sofie Vanhouche ${ }^{2}$
}

Received: 5 August 2020 / Accepted: 29 March 2021 / Published online: 23 April 2021

(c) The Author(s) 2021

\begin{abstract}
This article has three main purposes: (1) To describe an in-prison methodology for measuring the moral quality of life, developed organically out of experience and necessity. It is conducted over an intense but exceptionally brief period of time. (2) To reveal and reflect on our intellectual methodology: how do we describe, think, interpret and theorise about prison life in our work together, especially in a transnational team? (3) Finally, to consider the benefits and challenges of collaboration and intense immersion across national boundaries, in a study of Norgerhaven prison in the Netherlands. We found that our own implicit prison moralities varied significantly, as we worked together to describe a prison that surprised us, and our participants, hugely.
\end{abstract}

Keywords Team ethnography $\cdot$ Research $\cdot$ Reflexivity $\cdot$ Penology $\cdot$ Transnational prison

\section{Introduction}

Sunshine, space, stillness. There are 30 prisoners dotted about - sitting at tables, walking around the extensive grounds, doing exercises, playing badminton, football. There are 54 mature trees. We had an extremely smooth entry. There is such a calm atmosphere. Staff shake hands with prisoners; there is laughing between them. Prisoners are trickling into the theatre to complete our surveys. It's a good turnout. A passing officer says, 'Nice place here, eh? And the sun shines every day!' The lawn is being mowed. Staff love it. They have a very natural way of relating to prisoners. There is no authority showing - or only

Alison Liebling

al115@cam.ac.uk

1 Institute of Criminology, University of Cambridge, Sidgwick Avenue, Cambridge CB3 9DA, UK

2 Research Group Crime \& Society, Vrije Universiteit Brussel, Brussel, Belgium

3 Institute of Criminal Law and Criminology, University of Leiden, Leiden, The Netherlands

4 Norwegian Correctional Service (Kriminalomsorgen), Lillestrøm, Norway

5 Human Geography and Spatial Planning, Utrecht University, Utrecht, The Netherlands occasionally. Our liaison officer says, 'Don't go out of sight!' It is lovely to be able to do fieldwork outside. (Norgerhaven fieldwork notes, August 2017)

The editors of the Sage Qualitative Research Methods Series (Van Maanen, Manning \& Miller) argue that collective research projects 'have played a major role-in the art and science of the fieldwork trade' $(1998$, p. 6). They describe the spirit of team ethnography as 'emergent', 'communal', 'craftlike', 'interactive', and 'tentative' (ibid, p. 7). Doing fieldwork challenges us as individuals, wherever we do it (see Lurie, 1967). Combining voices, expertise, and perspectives in fieldwork-based projects, including in the writing up process, sits awkwardly with 'lone scholar' models of, and reward structures for, social research. It is especially challenging where several nationalities are involved, and the fieldwork site is a 'dual jurisdiction' or transnational prison.

This article has three main purposes:

1. To describe an in-prison methodology developed organically out of experience and necessity, which the authors and others have found to be productive and intellectually satisfying. The 'MQPL+' methodology (Measuring the Quality of Prison Life plus) generates depth and breadth, qualitative immersion and quantitative measurement, over an intense but exceptionally brief period of time, requiring a team of between six and ten research col- 
leagues. This approach suits our current time-pressed condition, but it also has legitimate benefits. We are often asked to communicate and explain it.

2. Unusually in social research, to reveal and reflect on our intellectual methodology: how do we describe, think, interpret, and theorise in our work together, in a team? How do good teams 'work'? What are the intellectual advantages and challenges of doing team ethnography?

3. Finally, to consider the benefits and challenges of collaboration and intense immersion across national boundaries, from the unusual vantage point of a mixed jurisdiction prison, and outline some lessons we have learned.

There is a developing, rich and useful literature on team research from a variety of social fields (including geography, health, education, and penology) which identifies the largely 'untheorised' politics and power dynamics of academic research teams despite the proliferation of large, interdisciplinary, and transnational research projects (e.g. Jarzabkowski et al., 2015; Mountz, 2003; Woods et al., 2000). Mountz et al. point out the strong links between steeply hierarchical institutional structures and research relationships that 'ooze with power' (Mountz et al., 2003, p. 36). Much of this work describes the methodological challenges, conflicts, tensions, and frustrations present in what is often 'hierarchical' teamwork, but most authors also welcome the complementary and 'stretching' effects of collaborations in fieldwork, recognising that 'negotiating difference' can be a productive part of the research process (e.g. Erickson \& Stull, 1998; Mountz et al., 2003; Scales, 2008). The situated and contested nature of knowledge (Gerstl-Pepin \& Gunzenhauser, 2002; Wasser \& Bressler, 1996; Jefferson, 2021) makes what individuals bring into a team deeply significant. Jarzabkowski et al. (2015, p. 8) and others (e.g. Mauthner \& Doucet, 2008) argue that team ethnography is a 'distinctive academic mode of production' that is proliferating, but the processes of intellectual as well as fieldwork collaboration, and the links between team methodologies and the kinds of knowledge or shared understandings produced, are rarely discussed. ${ }^{1}$

In this paper, we describe an unusual project—a transnational team ethnography - carried out in a peculiar prison, which brought to light, and challenged, some of our taken for granted assumptions about how each of us did research. Questions of seeing and not seeing, national identity, and scientific outlook became visible or articulated as we negotiated our way into the field, through the data analysis, and

\footnotetext{
$\overline{1}$ We should distinguish between team ethnography as we describe it here and 'collaborative ethnography', in which academics and participants work and write together (see Lassiter 2005) even if these boundaries can be blurred.
}

into the writing process. We knew from the start that Norgerhaven prison (which we introduce briefly below) was a complex and controversial site that a lone scholar would not be able to penetrate easily. That we were a 'transnational team' (of friends and colleagues) in the project we describe in this article, speaking different languages and steeped in distinct disciplines and penal cultures, made the task both attractive and complex. Whilst there were differences in seniority and experience amongst us, we tried to make the process as egalitarian and collaborative as possible. ${ }^{2}$

\section{Norgerhaven Prison}

Norgerhaven prison in the Netherlands was adapted to house Norwegian prisoners under a legal arrangement negotiated between the Netherlands and Norway in 2015 (see also Pakes \& Holt, 2017). Norway had too many prisoners, and a growing 'queue'. In the Netherlands, the prison population was in decline, prisons were closing, and staff were losing their jobs. Here was an apparently promising solution which was also an act of international cooperation and diplomacy. This was the second 'transnational prison' established to solve the problems of too many prisoners in one country and 'too few' in another (the first was Tilburg, also in the Netherlands; see Beyens \& Boone, 2015).

An experienced Norwegian Governor was placed in charge of the prison, which operated according to Norwegian Penal law. A Dutch senior manager had oversight of the facilities and the Dutch personnel, who were mostly prison officers. The Norwegian Director was responsible for the treatment of prisoners and the Norwegian staff.

The prison had a diverse prisoner population (a mix of Norwegian citizens and foreign nationals from across Europe, and elsewhere), with a range of languages spoken and cultures represented. Some were involuntarily transferred to Norgerhaven from Norway. The Dutch staff who looked after them were pleased that their prison was kept open and their jobs were secure, 'at least for a while', so there were vested interests among them. All staff had to undergo training provided by the Norwegian prison service before the rental period began. The training consisted of courses in Norwegian law, rules, and regulations concerning the transfer of prisoners (by airplane) to and from the prison, and social work. The working language was English.

\footnotetext{
${ }^{2}$ It was significant that a majority of us had, and others were soon to take up, tenure, or permanent employment. Three of us were full professors. Our diverse characteristics included nationality (Dutch, Norwegian, English, American, Belgian), language proficiency (Dutch, Norwegian, English, French), professional status (early career and more experienced researchers), discipline (sociology, criminology, law, sports science, political science), and experience.
} 
The Norwegian authorities were under significant pressure to make this 'experiment' a success and faced ongoing scrutiny following a death in custody and a critical Ombudsman's report (2016) suggesting, amongst other things, high levels of drugs in the prison in its early days. It was important, politically, that the prison was 'not meant to be a great experience' (senior manager) and yet both countries were famously 'liberal and humane' in their penal practices (Downes, 1988; Pratt, 2008; Pratt \& Eriksson, 2013; but, see also Ugelvik \& Dullum, 2012; Smith \& Ugelvik, 2017). Our research was, at first, experienced as a bit of an unwelcome threat. Labour unions in Norway had objected to the exporting of officer labour to a country that paid its staff less. There were other problems. Two countries who assumed their penal values and practices were basically alike discovered that this was not the case.

\section{Adapting the MQPL+ Methodology}

The study was commissioned and funded by the Norwegian prison service and was intended to assess the prison's quality. The two commissioned researchers, who worked for the Research Department at the University College of Norwegian Corrections Service, approached the lead author to request use of the Cambridge University's Prisons Research Centre's 'moral performance' survey. This survey was originally designed to conceptualise and measure some of the 'intuitively perceived' but difficult to measure moral qualities of prison life: staff-prisoner relationships, respect and humanity, safety, and the use of authority. It was originally developed out of qualitative research involving the use of Appreciative Inquiry (AI): a creative exercise seeking 'peak' or exceptional experiences (Liebling, assisted by Arnold, 2004). AI is designed to get to the heart of 'what matters'. The resulting questionnaire has been used in many jurisdictions, has high face validity, and an early version of it had already been used in Norwegian prisons. The appeal of the MQPL survey to prison service organisations was that it seemed to capture something real and recognisable about the quality and culture of a prison, but its mechanical or overly managerial use left behind its true spirit and value, which was its grounding in complex experience. It worked best - that is, facilitated good understanding of a prisonwhen it was used as part of a more qualitative exploration, by well-trained eyes.

After some discussion, the Norwegian team invited Alison Liebling to lead the study in order to implement the more qualitative version of it: a research exercise known as 'Measuring the Quality of Prison Life plus' ('MQPL+'). This is a quasi-ethnographic application of the MQPL (prisoner) and SQL (staff quality of life) surveys we refer to as 'ethnography-led measurement' (Liebling, 2015). This methodology has become highly refined, and is very efficient, but it is also adaptable. It requires the use of a (largely) experienced team, relying on their cumulative expertise as well as the availability of a suitably 'grounded' questionnaire. Cambridge University's Prisons Research Centre team have carried out 32 MQPL+ exercises in 24 prisons (4 outside England and Wales) since 2011, mostly on request, from Governors or the Prison Service. Six were longitudinal studies (see e.g., Liebling et al., 2015). Once this proposal took root, a second PRC member was recruited to help develop and lead this exercise. The methodology is, the PRC members realised as they described it to their Norwegian colleagues, unusually intense. We needed others. Where were we going to find a suitable and willing team?

\section{Assembling and Organising a Research Team}

The funding available did not include salaries, although expenses were covered. On the other hand, this was an attractive project for experience-hungry, curious, researchexcitable colleagues, who might be willing to dedicate their so-called holidays to a unique prison project. We set about devising our penological 'dream team'. This was the penological equivalent of playing 'fantasy football'. We each thought of others who would add expertise, language, and experience, who we were eager to work with, and who might be willing. The other team members were selected for their research expertise, but also for their kind natures and probably, albeit less consciously at the time, their relatively moderate politics: none of us were radical activists, or pursuing personal agendas. It was easy to think of people we had always wanted to work with, as a result of interactions at conferences, exchanges of teaching, or exposure to each other's work. Some of those invited suggested other colleagues, and their judgments were trusted. We were all naturally invested in 'joint intentional collaboration' (Tomasello \& Rakoczy, 2003) as well as in understanding prisons. We were eight women and two men.

Everyone we approached said 'Yes'. The Norwegian lead was in charge of organisation, access, accommodation and logistics. The Cambridge pair was to lead the methods. Everyone was to bring experience, curiosity, research skills, and energy. For the time we stayed together, close to the prison, we would dedicate ourselves entirely to the project. We reflect on how the team 'worked' in practice later.

The fieldwork took place in the spring and summer of 2017 , in a remote and beautiful part of the Netherlands. We shared accommodation in an attractive guesthouse with outdoor seating, a restaurant and bar, and surrounded by fields and sheep. We were all a little beleaguered and frantic in our ordinary working lives. The 'distraction and fragmentation' of our usual academic worlds fell away (Berg \& Seeber, 
2016, p. 90), as we created an un-corporate space for 'proper study' (Hardy \& Hausheer, 2013). Somehow we managed to slow down time (see Berg \& Seeber, 2016) in order to create a space for 'reflection, deliberation and dialogue' (ibid p. 11) alongside focused data collection. The experience felt like 'a retreat', like being on a timeless island, and yet also like deeply intense 'edgework' (Ferrell \& Hamm, 1998). ${ }^{3}$ Our universities would barely recognise our voluntary engagement in this kind of project (these days) as it does not fit the current model of 'research capitalism' (Berg \& Seeber, 2016, p. 53). We were escaping the commercial routines of our university lives to explore a different aspect of globalised capitalism: the trading of prisoners across borders.

\section{Navigating the Field: Building Trust and Negotiating Access}

We had official permission by the Norwegian authorities to conduct the research, but now trust and cooperation had to be established. A crucial moment in gaining informal access to the field was a preliminary dinner held with the key actors of the prison (the Norwegian Governor, the Dutch facility manager, and their deputies), at our invitation. It was held in a small, ancient local restaurant close to the prison, with a formality allowing for ritual, organisation, and intimacy. There was much at stake due to the political sensitiveness of the Norgerhaven project in both Norway and the Netherlands. The research had been 'inflicted' on the Governor, at the request of the Norwegian Prison Directorate. Because we realised that formal access would not be enough to create an open field, we thought that a meeting over dinner would be a suitable and informal opportunity to clarify our motives and start to build a relationship with our gatekeepers. Although we were well aware of the risky and controversial aspects of social hospitality ('losing objectivity', 'buying cooperation'), this informal gathering turned out to be an outstanding 'kick start' for our project. Our gesture was intended to communicate respect and gratitude. We knew that we were asking for trust. We wanted to get to know our research participants as 'complex, multi-sided, rich and engaging' people (Hardy \& Hausheer, 2013, p. 14), who were more than able to share their own understanding of their roles.

The meeting was long, the meal was superb, and as Erickson and Stull $(1998$, p. 8) suggested, coming together over food was a meaningful way to start a relationship. We explained our objectives and values, heard much about the early life of the prison and its climate, and developed a good

\footnotetext{
${ }^{3}$ Any research in prison is fraught with emotional and moral turbulence, however attractive the physical surroundings. Most prisons research takes place in more dysfunctional and challenging settings.
}

understanding about how to proceed with our methods, and in what order (the 'operation' was a complex logistical exercise). We received excellent advice-about the timings of each phase of the research, and about how to introduce the study to staff and prisoners. As the evening went on, we talked of Norwegian and Dutch life and culture, built trust, and negotiated 'real access' to the field. The Norwegian senior managers had committed significant aspects of their lives to this project: moving to Norgerhaven, or working away from home, taking responsibility for a major international project, and working long hours to problem-solve in new territory. We wanted to move through paradoxes and subtleties, refusing to caricature or oversimplify. This long, 'appreciative' meeting set the moral and methodological scene and established the 'high personal engagement' style of the research group. We asked sensitive questions, showed evidence of understanding, and revealed some of our own investments in pursuing knowledge. In return, this group of senior managers shared their own personal and professional perspectives and some anxieties. The dinner conversation was mutually exploratory and revealing. These kinds of conversations and encounters set up moral obligations and tensions: First, do no harm. Second, pursue the truth. Third, treat each individual's account as a precious gift. On the other hand, disentangle empathy from any tendency towards 'over rapport' (O'Reilly, 2009): never stop taking notes, in the moment or shortly afterwards.

We explained that our intention was to understand how Norgerhaven was experienced by prisoners and staff: How did it work? What did staff-prisoner relationships look like? How did they make sense of this 'experiment'? How do two distinct prison services work collaboratively together to run a prison? How do they negotiate differences? Could such a prison be legitimate? We held these.

\section{In the Field}

The main fieldwork in Norgerhaven was carried out in two phases (May and August 2017). The first period focused on the completion of the Staff Quality of Life (SQL) survey, including an all staff meeting to introduce the team and the study, and the initial building of relationships with prisoners. In the second phase, we re-established rapport with staff and spent the remaining time engaging with prisoners and staff, administering the MQPL surveys, and observing daily life at Norgerhaven. In total, the team of 10 researchers ${ }^{4}$ spent

\footnotetext{
4 The core team consisted of the 8 co-authors of this article. Yvonne Jewkes and Kristian Mjåland were invited to join the team for as long as they could manage (2-3 days each) to offer additional insights on prison design and Norwegian prisons, respectively.
} 
sixty person-days in the prison. ${ }^{5}$ It was surprising how little our presence appeared to disrupt life in the prison (although we may not be the best judges of this). We were armed with translated questionnaires and chocolate biscuits, intended to thank participants for completing the surveys. We introduced some tailor-made items into the survey, relevant to Norgerhaven's special features, based on our early conversations with staff and prisoners. We made the survey available in Norwegian, English, Spanish, Polish, and Lithuanian. The literal translations of the surveys ${ }^{6}$ meant that the conceptual meaning of some items was unclear. Despite this limitation, the surveys provided a tangible way to engage with prisoners, and the mistranslations often led to fruitful discussions about what 'fairness' or 'respect', for example, meant in this context.

\section{Day 1: The Full Staff Meeting}

We had learned in previous studies that including staff in the research was fundamental, and that the best way to do this was to hold a full staff meeting followed by focus groups, at the earliest possible stage. Around 100 staff and senior managers attended the meeting, organised at our request. This level of attendance demonstrated a willingness to engage with the research, or, at least, a polite receptiveness to their Director's encouragement to participate. One of the Dutch-speaking members of the research team, who had been involved in the Tilburg study, gave a short presentation, which we had prepared collectively in advance, introducing the group and the study, and explaining our methodology and the content of the survey to the staff. We advertised our previous experience, our understanding of the work of prison staff, and stressed the anonymity and confidentiality of the research process. There was room for questions. One of the first was 'well, what happened to Tilburg?' Some of the staff were aware (but others were not) that Tilburg had been closed at the end of its second contract extension (for mainly financial reasons) despite the research finding that the prison, and particularly the staff, were positively evaluated by prisoners, and that the staff were very happy in their work there (Beyens et al., 2013). So, the question in the minds of staff was how the current study might impact

\footnotetext{
5 This is the number of in-prison fieldwork days. There was much preparation and analysis time in addition, and observation of the movement of prisoners from Norway to Norgerhaven and back. We spent around 500 person-hours in the prison. See also Johnsen et al. (2017), Liebling et al. (2020).

${ }^{6}$ We prefer detailed, conceptual translations that reflect local culture and context. Due to time constraints and for ease of data entry and analysis, literal translations of the surveys were used for this study.
}

their future. This clearly expressed their fear that something similar would happen to Norgerhaven, a concern that also came up in the staff focus groups. We acknowledged that this was a critical time in the prison's history and emphasised our interest in documenting the prison's strengths, accomplishments, and challenges, as well as the voluntary nature of the exercise. In a similar way to our dialogues with prisoners, staff seemed satisfied to air their views, express any anxieties, and then engage in the survey. We made no promises, except to represent the findings authentically.

The Dutch and Norwegian staff completed the survey, chatted with each other and with us, and then we loosely organised those who were willing into groups, based mainly on language (Dutch, Norwegian, and English). We had a basic guide to inform our questioning, which primarily focused on asking staff to reflect on the transition to reopening Norgerhaven with prisoners from Norway, and the ways in which their professional work and life in the prison had changed as a result. We infused 'appreciative' questions into the discussion, encouraging staff to think about their 'best days' in the job, achievements, and proudest moments (Liebling, Price, \& Elliott, 1999). These questions were 'reassuring' and (staff often say) unexpected. Our aim was to get a well-rounded articulation of their values and practices. Many interesting themes arose from the Dutch focus groups: the future of their prison and the security of their jobs; the complexity of the project and the differences between Dutch and Norwegian penal practice; and some confusion and conflict about the Norwegian disciplinary system (see Liebling et al., 2020). Already, the main challenges of this 'experiment' for them were being revealed. The two jurisdictions had assumed that they were basically alike in their values. This turned out not to be the case.

Given the previous research experiences of some team members in Norgerhaven (Beyens \& Boone, 2013), some staff recognised two members of the research team. Having familiar faces return to their prison rekindled rapport and provided reaffirmation of our intentions and enduring interest: we wanted to understand their new working world, compared to their previous experience with 'their own' prisoners. Despite having housed a settled and sympathetic long-term population formerly, the Dutch staff argued that 'Norwegian prisoners' were 'easier', 'more compliant', and 'more polite'! In the end, 'knowledgeable interest' appealed to most of the staff, and they began to open up. They appreciated the research engagement. Significantly, some staff came in over the weekend, or on a rest day, in order to tell their professional stories at leisure, at a table in the outdoor courtyard. 


\section{Approaching Prisoners}

We also had to gain trust from prisoners in Norgerhaven, especially as we caused the prison's lockdown during the all staff meeting and somewhat 'invaded' and disturbed the prison routine with our presence. We tried to make up for this by inviting prisoners to come to the 'soos', an indoor social space with a café open to staff and prisoners, at any time that we were there. We offered coffee and chocolates and gave participants ample time over several days to share their experiences with us and complete a survey. Our large number, and being around all areas of the prison, gave prisoners the opportunity to fit the research into their schedules or to take time to decide whether they wanted to engage. We wanted to be responsive to life in the prison, movements, the flow, and the outdoor-friendly architecture. Instead of holding focus groups inside, and at times that competed with gym sessions or other activities, we attuned our methods to the rhythm and design of the prison. We relocated ourselves to the outside space and mingled with prisoners and staff on benches and at tables. We engaged in lengthy one-to-one conversations, some of us scattered around the prison's outdoor landscape, on benches, and under trees, or in relaxation areas such as the gym or library, so these 'meetings' felt leisurely and relaxed. We generally waited for prisoners to approach us, with questions about who we were and what we were doing there. We had prepared flyers and posters with our photographs and names, and an outline of the research, making it clear that participation was voluntary. Prisoners and staff appreciated the fact that we were listening to their narratives and the fact that some could express themselves in their mother tongue. For prisoners, this was something many of them missed given the lack of (frequent) visitors-the Belgian researchers could speak French with a Moroccan prisoner who had lived in Brussels, for example. However, we, like staff, occasionally needed prisoners to translate to others, as we were not able to speak an Eastern European language. In this sense, the research had some "collaborative' moments.

Our very visible presence around the establishment had the advantage of raising prisoners' interest. We were noticeable because we were not in uniform, did not look like prison staff, had not been seen before, and we were disproportionately female. The grounds were large enough that prisoners who did not want to participate in the study could keep a distance. In the end, prisoners (and staff) invited us to their units for tea and coffee, and to a shared Ramadan meal they had cooked, or they initiated a conversation ('who are you, then?') from an outdoor bench. We always asked permission to 'sit down and chat'. We found the right language, and let the conversation develop as naturally as possible. Some preferred to talk in two's and three's (socially, the prisoners tended to hang out in language groups, unsurprisingly). Others appreciated a one-to-one discussion. We tried to judge each encounter, and location, sensitively. Prisoners often suggested areas we should visit, or places we should linger. Some expressed regret that we would not be there long enough to join in with the 'annual fishing competition'.

\section{Operation 'Observe and Describe'}

The fieldwork was short but intense, with each of us covering different parts of the prison, or gravitating towards areas we felt at home in, or were most curious about. The surveys provided 'the hinge' and enabled us to 'roam free' in all other respects (see also Gariglio, 2016).

At the earliest stages of the research, the less experienced 'MQPL + sceptic migrants' in our team were nervous or critical about what initially felt like a rather unstructured process, or a departure from their training in 'scientific methods': there was no research script (or overt question), no digital recordings or transcriptions of the interviews, no 'selection' of respondents, and no observation plan. Deliberative debriefings replaced transcription and coding, and in many ways, kept us closer to the data (see Gerstl-Pepin \& Gunzenhauser, 2002). Trust had to be placed in the process, as well as in the more seasoned MQPL researchers, who had always worked in fairly intuitive ways (albeit with a familiar and 'homegrown' team).

Gradually, the art of trusting our instincts, being open and curious, following leads, accepting invitations, asking questions and exploring puzzles worked, particularly when we could check between us which areas we were beginning to understand, and which we were unsure about (see Anderson, 1961). We 'analysed' (or rather, synthesised) the qualitative data intersubjectively and in situ, as we debriefed at every meal and long into the evenings, each of us taking notes and reviewing our progress. ${ }^{7}$ We compared and contrasted experiences and encounters and drew from our individual expertise to make sense of what we were observing. This process assisted us in finding 'collective insight' in order to form a cohesive narrative (Jarzabkowski et al., 2015). Towards the end of the week, we organised our thoughts more systematically, drawing out themes and identifying

\footnotetext{
7 Analysis means 'detailed examination of anything complex in order to understand its nature or to determine its essential features' (Stanford Encyclopedia of Philosophy https://plato.stanford.edu/entri es/analysis/s1.html). We worked the other way round-from immersion and detail to synthesis, discovering ideas, but also reaching for already developed conceptual terms that helped us arrange our thoughts about what we were seeing. Later, drawing on the quantitative data in addition, our analysis became more systematic, and refined, but the basic elements remained intact.
} 
differences between the penal systems we knew well and what we were seeing here. Team dialogue, in this sense, served as an interpretive tool in the analytical process (Wasser \& Bresler, 1996, p. 6; and see Reiter et al., 2021).

Erickson and Stull (1998, p. 11) argue that group research is especially well suited to studying 'big' issues like immigration, intergroup relations, and the structuring of ethnic diversity. This is, in part, because ethnographic inquiry in a team transcends individual limitations by pooling expertise (ibid, pp. 3-4). Members of the group brought complementary skills, but also distinct expectations, which allowed for greater reach than any of us would have managed on our own, and enhanced interpretation and understanding (Erickson \& Stull, 1998, p. 21). We had 'many eyes' in all areas of the prison, 'separately and together' (Scales et al., 2008). Our individual expertise and experience allowed us to 'see the same thing differently' (Erickson \& Stull, 1998, p. 18). This aided us in comparing, contrasting, validating, and triangulating our data - a form of 'collective self-reflection' (Schratz, 1993).

Some team members, for example, noticed the absence of birds, because they had been present before, in Norgerhaven, or because they used to be present more generally in long-term prisons:

In my notes I find several reflections (some with officers) on the absence of the birds in the cells. During the first Norgerhaven study, prisoners were allowed to keep birds in their cells which gave the place (in my opinion) a cosy feeling. Their absence was striking and officers stressed that they preferred it liked this. It was quieter without the birds (I preferred the atmosphere in the cells with the birds though). (Team member, email exchange from fieldwork notes)

We also interpreted staff-prisoner relationships differently. Some of us thought relationships seemed relaxed, friendly and respectful. Others thought staff were too 'laidback' and too distant. This took some working out. Whilst we observed professionally competent behaviour, and friendly attitudes, we also noticed that staff spent much of their time either in offices or at the doors of the edge of the courtyard. They were accessible and helpful, but reactive rather than proactive. The staff had friendly and casual conversations with prisoners, but these were kept at the surface. Most of the staff did not really 'know' their prisoners, their stories, who was on or off the wings, or what prisoners' routines were like. They viewed this as being 'intrusive'. They were more focused on maintaining order than engaging with prisoners or their 'rehabilitation' (Johnsen et al., 2017). These fine distinctions turned out to be critical.

As a team, we each supplied different pieces of the jigsaw, responding in distinct ways to a picture we all could see was there, once we had all the pieces. To get to this point, we needed to contextualise these complex staff-prisoner dynamics by exploring 'the substantive comparative base, and the interpretive perspective through which those comparisons are made' (Woods et al., 2000, p. 94). Staff were having the same deliberative conversations that we were having as they went about their daily practice.

Dutch officers had to negotiate, defend, and adapt their everyday practices in the light of questioning, critique or opposition from the Norwegian authorities. The Norwegian senior team, on the other hand, had to explain, insist, or compromise when Dutch staff explained their reasoning, and trust in their own traditional practice. These reflexive conversations went on continually, and included disciplinary procedures, the use of segregation, movements around the prison, the length of the prison day, religious provision, visits, the organisation of work and prisoners' pay, access to sexually explicit DVDs, the approach taken to 'soft' versus 'hard' drug use, and the question of privacy (should prisoners' names be on cell doors?). These discussions were linked to a larger underlying question, still tacit, about what staff-prisoner relationships were for. The answer to that question determined what they should look like. We were wrangling with the same questions in our struggle to 'get the description right'.

The stated values of each correctional service may have been aligned, but the meaning of these values, once translated into practice, varied. Concepts travelled, but they changed their shape (Karstedt, 2012; Nelken, 2010). Practices were rooted in the meaning of words, but the meanings (e.g. decency, humanity, freedom) were implicit: Which is more decent—care or privacy? Should violence against staff be prosecuted? How much responsibility should staff have, and for what? What role do prison staff play in the rehabilitation of prisoners? The extent of this variation came as a complete surprise to both the Dutch and the Norwegian authorities. It also came as a surprise to us. So did the realisation that we each held different positions on these subjects ourselves. In both cases (between staff, and between us), the differences were revealed via dialogue.

After some deliberation, we worked out that in Norway, prison staff were engaged in, and trained for, a 'change' and rehabilitation process. Their emphasis was 'pedagogical'. Offence-related talk with prisoners was common and encouraged. Intervention was required. This was a future-oriented and arguably paternalistic approach (working towards reintegration post-release). In the Netherlands, prison staff worked towards 'good order' and providing a humane and relaxed space for prisoners to do their time, 'alone' if they wished (a present-oriented model; see Liebling et al., 2020). The Dutch prioritised 'freedom from', and even 'leniency', over 'correction' (arguably, a form of 'freedom to'): 'you can choose for yourself here'; 'I don't want to idealise, this is not paradise'. The Dutch approach to disciplinary procedures 
was swift and discretionary compared to Norway's slower and more bureaucratic model, grounded in the protection of liberty: 'It is a terrible responsibility to give people more time' (Norwegian senior manager). The Dutch were more explicitly committed to 'being egalitarian'. We identified this basic distinction between a present-autonomous or future-paternalistic orientation or perspective throughout the fieldwork and analysis process. Each jurisdiction, and therefore the staff who carried out prison work, used key concepts-justice, normalisation, humanity, punishment, discipline-differently. At one point, a senior manager said, whilst thinking-out-loud about the other jurisdiction, 'I mean, how do they bring up their children?' The differences went deep.

Only by talking together, across several countries, did we work out that the differences we were seeing were systematic, specific to each jurisdiction, and grounded in distinct penologies. Two different models of punishment were moving into focus ('The Norwegians start with trust; the Dutch start with distrust', as one prisoner remarked). Within the team, we each viewed staff and their professionalism through different lenses, given our own jurisdictional expectations and divergent views on the purpose and aims of imprisonment (and therefore the role of staff). We debated the advantages and disadvantages of the two approaches, once we had identified them, as well as the legitimacy (and limits of) Norgerhaven prison as a model of 'humane containment'. The Norwegian team members saw staff-prisoner relationships in Norgerhaven as 'superficial' and staff as somewhat indifferent, in this respect (just as some of the Norwegian senior managers did, in interviews). Other team members thought the dynamics were respectful and affable: that 'noninterference' was penologically defensible, especially when compared with the intrusive correctional model found in the UK and elsewhere (see Warr, 2019). Some staff thought the Dutch model was 'too laissez-faire' (relaxed). The complexities of this process of coming to an understanding or moral diagnosis was compounded by prisoner narratives, which were, at times, at odds with each other, depending on citizenship: Norwegian prisoners felt disadvantaged by being in Norgerhaven, as they were not able to access the same kind of support and opportunities they would have back home, whilst foreign national prisoners discussed feeling better and more 'equally' treated than in Norway, where they were often excluded from its apparent 'liberal humanitarian/welfare-ist', but also correctionalist, penology. This was one of many occasions where we deliberated on the interpretation and construction of knowledge (Creese et al., 2008, p. 213).

'Being there' together was critical in order to make sense of this methodologically, morally, and politically complex field site and helped to illuminate and unpick the nuances of everyday life in the prison. In the end, identifying and describing these "two contrasting penologies' was helpful, to us and to the prison, and was more important than trying to decide which one was 'right'. There were more differences to come.

During our last evening debriefing the team took a vote on the rental of Norgerhaven, as this was currently being debated by the Norwegian authorities. This final 'over dinner' conversation-'So, do you think the contract should be extended?'-was daring, as each of us declared a position. Underneath each answer (they were not all the same) lay acres of not yet articulated feeling, conviction, preconception, and politics. We had to 'go for the jugular' (ask ourselves the right, pertinent, loaded question, out loud) to complete the investigation. What were we doing there? Had we done the task justice? We disagreed, on the question of the contract, but came away respecting each other's views and able to agree on a deep reading of the prison. There was generative value in this 'conflict', as we each articulated our moral or political position to the group. Instead of destabilising the team, this discussion led us into a more nuanced examination of how we understood and interpreted transnational prisons (Scales et al., 2008, p. 26). By then, the team dynamic allowed for these kinds of dialogic (and respectful) 'safe spaces' (Gerstl-Pepin \& Gunzenhauser, 2002, p. 151), which was crucial in advancing our collective thinking.

Mutual play (these long evenings over food and wine) allowed for some real resistances to others' interpretations to be aired, exposed, and negotiated. We had national allegiances, political sympathies, cultural assumptions, emotional understandings, blind spots, as well as epistemological frameworks. We were human beings, trying to understand, or maybe defend, an 'outrageous' and barely visible prison. That some prisoners preferred it to other prisons in Norway puzzled and challenged us. Identifying our own, and each other's, 'strong expectations' or 'intellectual desires' made it easier to allow all 'the facts', welcome and unwelcome, 'to vibrate' (Stitzman, 2004, p. 1144). This process caused discomfort but enabled us to collectively separate 'the wheat [plausible interpretations] from the chaff [false assumptions]' (ibid). Perhaps we gained in tolerance of such discomfort with experience. Unlike Barry et al (1999), who advocate trying to be reflexive at the start of a team project, we were not able to reach this stage properly until the end. We did not know what our own presuppositions were.

The next day (our last), we heard that the Norwegian prison service would not extend the three year contract. We gave organised verbal feedback to the senior management team. This resulted in an extensive and honest discussion including about future planned improvements: 'This prison would not be built now. It is a rich prison, historically, and in relation to the experience that is here'. Its time was limited. 


\section{Reflections on a Team Ethnography}

The marvellous capacity of the human mind to make sense of a lifetime's collection of experience and to connect patterns from the past to the present and future is, by its very nature, hard to capture ... While individual creativity is important, exciting, and even crucial to business, the creativity of groups is equally important. (Leonard \& Sensiper, 1998, p. 112)

We started out in this project with (we thought) similar values in research and scholarship, but slightly different expectations of fieldwork. We liked each other and welcomed the opportunity to work closely together for the first time. Other team members had never met but were drawn in on the basis of 'trust by proxy'. We shared a profound love for prisons research, and for trying to 'see as if seeing for the first time' (Stitzman, 2004, p. 1140).

This was a 'best experience' of working in a team (most of us have had other kinds of experiences, at times). There were still challenges. How do team members know who ideas or interpretations are becoming evident to? For example, the lead author sometimes became frustrated when her practices had to be explained and defended, or when others seemed (to her) to be hesitant in their thinking-out-loud, for the purpose of 'working things out'. They might have just been (understandably) shy. Finding a balance between 'intellectual leadership' and 'generating spaces for others' contributions to appear', or collectively noticing who might be working towards a new thought, was tricky for someone who felt a responsibility to lead. Having reflected on this process, we can see the need for explicit attention to be paid to this; for several kinds of thinking and articulation space: differently configured groups, one-to-one dialogue, correspondence, and probing. Ideas evolved slowly, and unexpectedly, sometimes quietly: sometimes they had to be found. Oscillations between patience, uncertainty and accomplishment were necessary.

We learned a great deal more than we expected, despite a short research stay (we cannot know how far our findings may have changed if we had stayed longer). The main 'aha' moment was a realisation that this transnational prison forced its staff, from two different jurisdictions, out of 'practical' and into 'discursive' consciousness (see Sparks, Bottoms \& Hay 1996; and Giddens, 1986), as they discovered and negotiated differences in their values, criminologies, theories of punishment, and practices. 'Practical consciousness' is skilled action so grounded in experience that it is hardly noticed. Discursive consciousness is the ability to articulate this skill, or what we say about and how we understand what we do. We went through the same experience, being forced to articulate practices, reflections and responses to the field that we were otherwise 'taking for granted'.
Being able to express our reasons for action and thought helped us to become 'reflexive monitoring agents' (Giddens, 1986) and better prison scholars.

Our collaboration encouraged us to be more interdisciplinary (see Creese et al., 2008; Jarzabkowski et al., 2015) as well as more international. It increased our reach into the prison and provided respondents with a range of ways in which they could engage and share their stories, as we brought different identities, experiences, language skills, and expertise into the field (Scales et al., 2008). We had different habits and research orientations, as well as different ways of seeing. Our collective aim was to combine all the advantages of meaningful quantification (the survey) with a qualitative and collaborative foray into the prison. The methodological 'leaders' had not realised how intuitive their research style was. This aspect of the research, too, had to be articulated, and the term argued over, as team members challenged, reflected on, or defended, aspects of what we would normally take for granted:

Intuition is 'the sense ... that is capable of seeing' ... of 'perceiving connections' that might not at first sight be visible, that requires suspending, or holding back, 'the curiosity-ridden anxiety of arriving at facts and reason'. Sometimes the 'fleeting wild truth ... does not arrive by means of reasoning or slow preparation - but by surprise, revelation'. It 'exceeds' the existing 'thinking apparatus'. (Stitzman, 2004, pp. 1144-47)

Stitzman refers to psychoanalysis, but research can be like this too. We can develop a good 'radar' through experience, but we won't always know where to point it, or when it is likely to be at its most active. Sometimes we do not know why we ask certain questions, but we know 'from where' we ask it—we 'know that something must be conjugated there' (ibid, p. 1152).

In the end, we came to agree that what we decided to call 'practised intuition', grounded in expertise and accumulated knowledge, played a very important role in our research, despite some discomfort amongst some members of the team with this term (it was 'risky', or methodologically inappropriate). Intuition, as well as rigour, had always played a significant role for some of us, but those of us who relied upon it more had not articulated this aspect of our work before because it was so 'taken for granted'. Whilst social scientific methods provided a scaffold, judgement, feeling, and instinct guided us through each decision, each day, and towards each insight. It was not always possible to distinguish between 'practical consciousness' (built up experiential knowledge, or 'scientific intuition'; Miller, 1996) and good instincts, but a capacity to read a situation and know what it calls for, drawing on a wide range of information beyond 'scholarship', and cumulative experience, was essential to our research practice. We know much of what 
we know (for example, in a prison, that a riot is brewing, that violence is in the air, or that someone is upset), but we also often theorise, non-cognitively. Paying attention to the moods and sensitivities of those around us, the unspoken sub-text, the feeling in a room, and the connections between observations, required keeping the pathway to our intuitions or instincts fully open. Being receptive and questioning, and checking our readings against those of others in the team, produced better readings of complex situations than being certain, or slavishly following all the methodological rules (e.g. the gathering of a representative sample, or the strict following of the ordering of questions in an interview schedule, as ethical committees often expect). The idea of the dinner with senior managers on our first evening, before the fieldwork began, for example, just 'felt right'. It broke some methodological rules about levels of engagement and 'taking sides', but it felt to us, in an instant, that trust, as well as sensitivity, could be built via taking semi-social time to be real, attentive, and hospitable. We were walking into an international diplomatic experiment, in which people had invested their professional identities. Not to work through some understanding of what that felt like seemed neglectful. Feeling and care can be integrated into our work without us taking sides, or 'going native' (Belenky et al., 1997; Engelke, 2017).

Likewise, our struggle to 'read' the prison at first, and to position the staff, was linked to the presence of two competing models of criminal justice, which we could only identify once we helped each other to bring our own 'hidden penologies' out in the open. This was an inductive, intuitive, dialogic process.

Practical or 'intelligent' intuition looks out for the feel of the situation, for resonance, surprising connections, and creative possibilities. It involves cognitive and emotional resources working in tandem; an artist's as well as a scientist's imagination (Gompertz, 2015). Emotions are, after all, appraisals of experiences or thoughts-in this sense, they are also a form of information processing (van Mulukom, 2018):

In order to make our best decisions, we need a balance of intuition -- which serves to bridge the gap between instinct and reasoning -- and rational thinking ... There is a cultural bias against following one's instinct or intuition. We don't have to reject scientific logic in order to benefit from instinct. We can honor and call upon all of these tools ... By seeking this balance we will finally bring all of the resources of our brain into action. (Francis Cholle, 2011 The Intuitive Compass)

This is hard work. It requires time and sharpened sensibilities. It means 'seeing deeply', being fully present and connected, and staying agile and attuned at all times. It means holding plans in suspense, making decisions along the way, feeling our way through the fieldwork, solving unexpected problems, and interpreting puzzles moment by moment. It requires full engagement throughout. We worked at the edges of our competence, in intimate dialogue with each other, learning as much from our relatedness to others as we did from formal 'data'. 'Ethnography-led measurement' (Liebling, 2015) relies upon a kind of 'discerning' — trying to detect and articulate rather than create or impose a shape in the social universe. Here, we were doing this discerning together. It is a very 'alive' and often joyful way of doing research, even in challenging contexts. Intuition can be disciplined, shared, and tested. It is a skilled resource in social research (see Wright Mills, 1959). ${ }^{8}$

Doing this in a transnational team, asking questions of each other continually, helped to develop and refine our conceptual and theoretical instincts, made us more overtly aware of what was and was not 'there' in the field, and helped us to formulate an account that was informed by cultural differences and tensions as well as shared understandings. We pooled our collective experience, enabling insight to develop between us. Expressing these differences 'awakened the mind's attention from the lethargy of custom', and 'removed the film of familiarity' that sometimes obscures our vision. ${ }^{9}$ We developed both trust in, and scepticism about, our own instincts by sharing them with others.

Via these methods, we found our way to two different prison moralities, each inarticulate until confronted by another. We also identified our own, often for the first time, by 'occupying' the perspectives of distinct groups of staff, prisoners, and project managers engaged in a tricky experiment at the limits of penal legitimacy, trying their utmost to be professional, in a place where force and different models of penal justice collided. There were contradictions, and incompleteness, in our account. Participants sometimes gave very partial accounts of their model, or thought it was fading, in the Dutch case, beyond the special case of Norgerhaven. But there were also moments of insight and learning:

Our staff work the Norwegian way now. They do a second interview. It's exclusive to this prison. They ask about offending. That's not in our standard training.

(Dutch Senior manager)

Prisons interest us precisely because we see 'concepts in action', intensified, absent and present, and starkly made real. This project helped us to recognise more explicitly than we had before that there are 'interdependencies between concepts and the lives of people who use them' (Winch, 2008 , p. 20). This includes the concepts that researchers use, and the 'ideas' we can see.

\footnotetext{
${ }^{8}$ See especially his 'On Intellectual Craftmanship', ibid: 195-226.

9 Coleridge, on Wordsworth, in Preface to the Lyrical Ballads, 1802.
} 
Acknowledgements We would like to acknowledge the assistance of the Norwegian Correctional Service (KDI) for commissioning this research, staff and prisoners at Norgerhaven for their gracious assistance, and Irene Fortuyn for the invitation to AL and YJ to visit the site in 2016, and for inspiring our interest in the prison. We are deeply grateful to Luigi Gariglio, Prisons Research Centre colleagues, and our anonymous reviewers, for thoughtful feedback on a first version of this article.

Funding This research was partially funded by the Norwegian Correctional Service (KDI).

Data Availability The study was approved by the Norwegian Centre for Research Data (Project Numbers 53502 and 51243). Because of sensitivity, access to the data is restricted to the research team members.

\section{Declarations}

Conflict of interest Berit Johnsen and Tore Rokkan are employed by the Norwegian Corrections Service (KDI) Research Institute (KRUS).

Open Access This article is licensed under a Creative Commons Attribution 4.0 International License, which permits use, sharing, adaptation, distribution and reproduction in any medium or format, as long as you give appropriate credit to the original author(s) and the source, provide a link to the Creative Commons licence, and indicate if changes were made. The images or other third party material in this article are included in the article's Creative Commons licence, unless indicated otherwise in a credit line to the material. If material is not included in the article's Creative Commons licence and your intended use is not permitted by statutory regulation or exceeds the permitted use, you will need to obtain permission directly from the copyright holder. To view a copy of this licence, visit http://creativecommons.org/licenses/by/4.0/.

\section{References}

Anderson, N. (1961 [1923]). The hobo: The sociology of the homeless man. University of Chicago Press.

Barry, C. A., Britten, N., Barber, N., Bradley, C., \& Stevenson, F. (1999). Using reflexivity to optimize teamwork in qualitative research. Qualitative Health Research, 9(1), 26-44.

Belenky, M. F., Clinchy, B. M., Goldberger, N. R., \& Tarule, J. M. (1997). Women's ways of knowing: The development of self, voice, and mind. Basic Books.

Berg, M., \& Seeber, B. K. (2016). The Slow professor: Challenging the culture of speed in the academy. University of Toronto Press.

Beyens, K., Boone, M., assisted by Liefaard, T., Kox, M., Vanhouche, A., \& van der Poel, S. (2013). Zeg maar Henk tegen de chef. Ervaringen met het Belgische detentieregime in de PITilburg. Den Haag: Boom Lemma uitgevers. https://www.wodc.nl/binar ies/2037-volledige-tekst_tcm28-71806.pdf

Beyens, K., \& Boone, M. (2015). Mixing Detention cultures: The belgian-dutch case. In D. H. Drake, R. Earle, \& J. Sloan (Eds.), The palgrave handbook of prison ethnography (pp. 479-498). Houndmills, Palgrave Macmillan.

Boone, M., \& van Swaaningen, R. (2013). Regression to the mean: Punishment in the Netherlands. In V. Ruggiero \& M. Ryan (Eds.), Punishment in Europe: A critical anatomy of penal systems. Palgrave Macmillan.

Boone, M., Pakes, F., \& van Wingerden, S. (2020). Explaining the collapse of the prison population in the Netherlands: Testing the theories. European Journal of Criminology. https://doi.org/10. $1177 / 1477370819896220$

Cholle, F. P. (2011). The intuitive compass: Why the best decisions balance reason and instinct. Jossey-Bass.

Creese, A., Bhatt, A., Bhojani, N., \& Martin, P. (2008). Fieldnotes in team ethnography: Researching complementary schools. Qualitative Research, 8(2), 197-215.

Downes, D. (1988). Contrasts in tolerance: Post-war penal policy in the Netherlands and England and Wales. Clarendon Press.

Engelke, M. (2017). How to think like an anthropologist. Princeton University Press.

Erickson, K., \& Stull, D. (1998). Doing team ethnography: Warnings and advice. Sage.

Ferrell, J., \& Hamm, M. (1998). Ethnography at the edge: Crime, deviance and field research. Northeastern University Press.

Gariglio, L. (2016). Photo-elicitation in prison ethnography: Breaking the ice in the field and unpacking prison officers' use of force. Crime Media Culture, 12(3), 367-379.

Gerstl-Pepin, C. I., \& Gunzenhauser, M. G. (2002). Collaborative team ethnography and the paradoxes of interpretation. International Journal of Qualitative Studies in Education, 15(2), 137-154.

Giddens, A. (1986). The constitution of society: Outline of the theory of structuration. University of California Press.

Gompertz, W. (2015). Think like an artist ... and lead a more creative, productive life. Penguin Books.

Hardy, H., \& Hausheer, R. (2013). (Eds.). The proper study of mankind: An anthology of essays by Isaiah Berlin. Vintage Books

Jarzabkowski, P., Bednarek, R., \& Cabantous, L. (2015). Conducting global team-based ethnography: Methodological challenges and practical methods. Human Relations, 68(1), 3-33.

Jefferson, A. (2021). Prison ethnography in the pursuit of imponderable knowledge: A hesitant 'how-to' guide. In K. Jacobsson \& J. F. Gubrium (Eds.), Doing human service ethnography. Policy Press.

Johnsen, B., Rokkan, T., Liebling, A., Beyens, K., Boone, M., Kox, M., Schmidt, B. E., Vanhouche, A. S., Mjåland, K., \& Jewkes, Y. (2017). Measuring the quality of life at Norgerhaven prison report. http://www.krus.no/norgerhaven.6114765-286892.html

Karstedt, S. (2012). Comparing justice and crime across cultures. In D. Gadd, S. Karstedt, \& S. Messner (Eds.), The sage handbook of criminological research methods. (pp. 373-389). Sage Publishing.

Lassiter, L. E. (2005). The Chicago guide to collaborative ethnography. University of Chicago Press.

Leonard, D., \& Sensiper, S. (1998). The role of tacit knowledge in group innovation. California Management Review, 40(3), 112.

Liebling, A., Price, D., \& Elliott, C. (1999). Appreciative inquiry and relationships in prison. Punishment \& Society, 1(1), 71-98.

Liebling, A., assisted by Arnold, H. (2004). Prisons and their moral performance: A study of values, quality, and prison life. Oxford University Press.

Liebling, A. (2015). Description at the edge? I-It/I-Thou relations and action in prisons research. International Journal for Crime, Justice and Social Democracy, 4(1), 18-32.

Liebling, A., Schmidt, B.E., Crewe, B., Auty, K., Armstrong, R., Akoensi, T., Kant, D., Ludlow, A., \& levins, A. (2015). Birmingham prison: The transition from public to private sector and its impact on staff and prisoner quality of life: A three-year study. Ministry of Justice.

Liebling, A., Johnsen, B., Schmidt, B.E., Rokkan, T., Beyens, K., Boone, M., Kox, M., \& Vanhouche, A.S. (2020). Where two 'exceptional' prison cultures meet: Negotiating order in a transnational prison. British Journal of Criminology, 61, 41-60.

Lurie, A. (1967). Imaginary friends. Heinemann.

Mauthner, N. S., \& Doucet, A. (2008). Knowledge once divided can be hard to put together again: An epistemological critique of collaborative and team-based research practices. Sociology, 42(5), 971-985. 
Miller, A. I. (1996). Insights of genius: Imagery and creativity in science and art. Springer.

Mills, C. W. (1959). The sociological imagination. Oxford University Press.

Mountz, A., Miyares, I. M., Wright, R., \& Bailey, A. J. (2003). Methodologically becoming: Power, knowledge and team research. Gender, Place \& Culture, 10(1), 29-46.

Nelken, D. (2010). Comparative criminal justice. Sage.

O'Reilly, K. (2009). Going native. in Key concepts in ethnography. Sage.

Pakes, F., \& Holt, K. (2017). The transnational prisoner: Exploring themes and trends involving a prison deal with the Netherlands and Norway. British Journal of Criminology, 57(1), 79-93.

Parliamentary Ombudsman's National Preventive Mechanism (NPM). (2016). Bes $\varnothing$ ksrapport Norgerhaven fengsel. pp. 19-22, September 2016 .

Pratt, J. (2008). Scandinavian exceptionalism in an era of penal excess. Part I: The nature and roots of scandinavian exceptionalism. The British Journal of Criminology, 48(2), 119-137.

Pratt, J., \& Eriksson, A. (2013). Contrasts in punishment: An explanation of Anglophone excess and Nordic exceptionalism. Routledge.

Reiter, K., Dallas Augustine, D., Melissa Barragan, M., Kelsie Chesnut, K., Gabriela Gonzalez, G., \& Natalie Pifer, P. (2021). Reflections on team research in carceral settings. In J. Schlosser (Ed.), Women scholars' experiences doing prison research. Lexington.

Scales, K., Bailey, S., \& Lloyd, J. (2008). Separately and together: Reflections on conducting a collaborative team ethnography in dementia care. Enquire, 4(1), 22-44.

Schratz, M. (1993). From cooperative action to collective self-reflection: A sociodynamic approach to educational research. In M.
Schratz (Ed.), Qualitative voices in educational research. The Falmer Press.

Smith, P. S., \& Ugelvik, T. (2017). Introduction: punishment, welfare and prison history in scandinavia. In P. S. Smith \& T. Ugelvik (Eds.), Scandinavian penal history, culture andprison practice: Embraced by the welfare state? Palgrave Macmillan.

Sparks, R., Bottoms, A. E., \& Hay, W. (1996). Prisons and the problem of order. Oxford University Press.

Stitzman, L. (2004). At-one-ment, intuition and 'suchness.' International Journal of Psychoanalysis, 85, 1137-1155.

Tomasello, M., \& Rakoczy, H. (2003). What makes human cognition unique? From individual to shared to collective intentionality. Mind \& Language, 18(2), 121-147.

Ugelvik, T., \& Dullum, J. (Eds.). (2012). Penal exceptionalism? Nordic prison policy and practice. Routledge.

van Mulukom, V. (2018). Is it rational to trust your gut feelings? A neuroscientist explains. Conversation, published online May 16. Available at: https://theconversation.com/is-it-rational-to-trustyour-gut-feelings-a-neuroscientist-explains-95086

Warr, J. (2019). 'Always gotta be two mans': Lifers, risk, rehabilitation, and narrative labour. Punishment \& Society, 22(1), 28-47.

Wasser, J. D., \& Bresler, L. (1996). Working in the interpretive zone: Conceptualizing collaboration in qualitative research teams. $E d u$ cational Researcher, 25(5), 5-15.

Winch, P. (2008/1st ed 1958). The idea of social science and its relation to philosophy. Routledge.

Woods, P., Boyle, M., Jeffrey, B., \& Troman, G. (2000). A research team in ethnography. International Journal of Qualitative Studies in Education, 13(1), 85-98. 